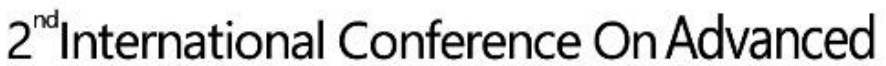 Research in HUMANITIES
}

\section{Dumbara Weaving: The Economics of Cultural Heritage}

\author{
S.Sulari Vindya De Silva \\ University of Moratuwa, Sri Lanka
}

\begin{abstract}
:
Dumbara textiles are produced in Thalagune, a little isolated village nestled in the Dumbara Valley in the central hills of Sri Lanka. This is Sri Lanka's oldest and the only remaining village dedicated to the hereditary craft of textile weaving. Ancient pieces of Dumbara textiles can be found today preserved in the Victoria and Albert museum in England, the national museums in Colombo and Kandy, Sri Lanka. The traditional textile weaver caste inhabits in this village still employs an age-old weaving process. Even though the country underwent numerous modern changes in social order today, the mode of production of the Dumbara weaving was not gripped by them and remained virtually woven to the patterns of the old feudal system. Faced with the challenge of survival as an industry, Dumbara weaving is adopting new ways about making their living in an economic sense. Under the capitalist system, the artisan or the weaver has become a Third World laborer and the artifact has been changed into a commercial commodity. However, Dumbara weaving embodies, stores and gives rise to cultural value in addition to the economic value it may possess at present. This study analyses the value and the meaning of Dumbara Weaving as a hereditary craft by examining the nature of craft production in the context of late-modern capitalist system. To understand the relationship between culture and commerce of craft, this study tests the conceptual framework of Heritage Economics developed (by David Throsby) as the most recent form of capital theory through investigating the attributes such as aesthetic quality, spiritual meaning, social function, symbolic significance and historical importance of crafts which can be economically valued. For sustainable economy, it is very much important to ensure the survival of craft culture as the way it naturally evolves.
\end{abstract}

Key Words: Dumbara weaving, heritage, craft, sustainable economy 